\title{
Rock temperature prior to failure: analysis of 209 rockfall events in the Mont Blanc massif (Western European Alps)
}

\author{
A. Legay ${ }^{1}$, F. Magnin'1, L. Ravanel ${ }^{1}$ \\ ${ }^{1}$ EDYTEM Lab, Université Savoie Mont Blanc, CNRS, Le Bourget-du-Lac, France \\ Corresponding author: Florence Magnin [florence.magnin@univ-smb.fr]
}

Key words: rockfall, alpine rockwall, thermal modeling, permafrost, Mont Blanc massif

2 Periglacial rockwalls are affected by an increase in rockfall activity attributed to permafrost

3 degradation. While recent laboratory testing has asserted the role of permafrost in bedrock

4 stability, linking experimental findings to field applications is hindered by the difficulty to assess

5 bedrock temperature at observed rockfall locations and time. In this study, we simulated bedrock

6 temperature for 209 rockfalls inventoried in the Mont Blanc massif between 2007 and 2015 and

7209000 random events artificially created at observed rockfall locations. Real and random events

8 are then compared in a statistical analysis to determine the results significance. Permafrost

9 conditions (or very close to $0{ }^{\circ} \mathrm{C}$ ) were consistently found for all events with failure depth $>6 \mathrm{~m}$,

10 and for some events affecting depths from 3 to $6 \mathrm{~m}$. Shallower events were likely not related to 
11 permafrost processes. Surface temperatures were significantly high up to at least 2 months prior to

12 failure with the highest peaks in significance 1.5 to 2 months and 1 to 5 days before rockfalls.

13 Similarly, temperature significances at scar depths were significantly high, but steadily decreasing,

141 day to 3 weeks before failure. The study confirms that warm permafrost areas $\left(>-2{ }^{\circ} \mathrm{C}\right)$ are

15 particularly prone to rockfalls, and that failures are a direct response to extraordinary high bedrock

16 temperature in both frozen and unfrozen conditions. The results are promising for the development

17 of a rockfall susceptibility index but uncertainty analysis encourages to use a greater rockfall

18 sample and a different sample of random events.

\section{Introduction}

22 Rockwalls can be affected by significant gravity-related transfers of material throughout rockfall,

23 defined here as the detachment of a mass of rock with a volume exceeding $100 \mathrm{~m}^{3}$ from a series

24 of discontinuities, and its transportation downslope on variable distance ${ }^{1}$. Rockfall is one of the

25 most hazardous geomorphological processes in Alpine massifs and can threaten mountain

26 infrastructure ${ }^{2-5}$, tourism ${ }^{6,7}$ and valley floors in case of major events ${ }^{8-12}$. Periglacial rockwalls have

27 been increasingly affected by rockfalls ${ }^{13-18}$, notably during summer heatwaves ${ }^{19,20}$ and permafrost

28 degradation is thus thought to be one of the main factors responsible for these increasing bedrock

29 destabilizations ${ }^{21-25}$. With the projected degradation of alpine permafrost ${ }^{26}$, these hazards will

30 likely become a major threat for mountain communities and a better understanding of the thermal

31 context leading to periglacial rockwall failure is therefore crucial.

32 Laboratory experiments conducted over the past two decades have extensively contributed to

33 understand how thawing bedrock may become unstable. In a first stage, Davies et al. ${ }^{27}$ have 
34 demonstrated that besides the normal stress, the strength of an ice filled rock joint is a function of

35 its temperature. It decreases with warming and reaches a minimal value at $-0.5^{\circ} \mathrm{C}$. Then, Mamot

36 et al. ${ }^{28}$ have refined this analysis showing a decrease of ice-filled joint resistance by a range of 64

$37-78 \%$ when the bedrock warms from -10 to $-0.5{ }^{\circ} \mathrm{C}$. Those studies agree with former

38 investigations combining field observations and heat conduction modeling to explain the link

39 between the thawing front propagation and boulder fall in periglacial rockwalls ${ }^{29}$. However,

40 Krautblatter et al. ${ }^{24}$ have lately explained that the rupture of ice filled joints may only occur at

41 depth $<20 \mathrm{~m}$ while, deeper, warming provokes slow deformation along rock-rock contact,

42 meaning that the rupture of ice-filled joints may only explain relatively shallow events. In addition,

43 laboratory experiments have also pointed out that ice-filled joint alteration may also result of

44 enhanced erosion provoked by water percolation and related advective heat transfer ${ }^{30}$. This is

45 supported by field investigations at rockwall sites showing thawing corridors through geophysical

46 soundings ${ }^{31}$ or sudden temperature increase in borehole ${ }^{32}$. Water infiltration and circulation may

47 also cause hydrostatic pressure in ice-sealed fractures that could contribute to rockfall

48 triggering $24,25,33,34$ as suggested by observations of water together with massive ice in rockfall

49 scars ${ }^{20-22}$. However, determining the role of hydraulic processes in alpine rockfall triggering is

50 challenging because of the lack of fully coupled thermo-hydro-mechanical numerical models and

51 data for parameterization ${ }^{33}$.

52 Despite these limits, the link between rock slope failures and permafrost conditions was confirmed

53 for various events using transient heat conduction models for specific rockfalls ${ }^{21,22}$ or through 54 comparison of permafrost map $^{35}$ and rockfall inventory ${ }^{26}$. Statistical analysis of climate variables

55 or rock surface temperature evolution also showed a strong link between air temperature anomaly

56 and rockfall occurrence in high mountain ${ }^{36-38,}$ while various studies explain that strong thermal 
57 oscillations and related cyclic thermal stress or thermal expansion related to heating may cause

58 rockfall in non-periglacial environments ${ }^{39-41}$.

59 Despite these advances, observations are generally too sparse or inhomogeneous to draw robust

60 statistical analysis of thermal conditions at depth of bedrock failure, which limits the understanding

61 of the link between rockfall and rockwall thermal dynamics and therefore our capacity to predict

62 rockfalls.

63 Our study proposes to investigate bedrock thermal dynamics prior to rockfall occurrence for 209

64 inventoried events during the period 2007-2015 in the Mont Blanc massif. It uses a 1D transient

65 thermal model ${ }^{42}$ simulating temperature-depth profiles at a daily time step. Absolute temperatures

66 simulated at the rock surface and at the depths of rockfall scars prior to failures are presented but

67 the main part of the analysis is based on a statistical approach in order to minimize biases in results

68 interpretation. Our study addresses the following research questions:

69 - Which bedrock temperature conditions or dynamics are the most prone to rockfall

$70 \quad$ occurrence?

$71 \quad$ - Is bedrock temperature experiencing exceptionally high value prior to failure?

72 - Is there a statistical relationship between bedrock temperature and rock slope 73 destabilization?

74 The study aims at verifying the hypotheses that the observed rockfalls are a direct reaction to the

75 intense and exceptional summer heatwaves that occurred over the past summers ${ }^{43-45}$, and that 76 thawing permafrost (close to $0{ }^{\circ} \mathrm{C}$ ) areas are the most prone to rockfalls. In this way, it intends to 77 better define the time-lag between the air temperature signal and the bedrock failure and to explore 78 a possible statistical relationship between air temperature, rock temperature dynamics and failure 79 occurrences that would help to predict such events with weather forecast. 


\section{Study area and rockfall database}

81 The Mont Blanc massif (MBM; Fig. 1), with its highest point at $4809 \mathrm{~m}$ a.s.1., is a crystalline

82 massif that extends over an area of $550 \mathrm{~km}^{2}$ in the Western Alps. It presents two main lithological

83 units: a Variscan metamorphic series in the W and SW of the massif, and an intrusive late-Variscan

84 granite in the central and eastern parts, crosscut by three main sets of shear zones and faults ${ }^{47}$.

$8527 \%$ of the massif was covered by glaciers in the $2000 \mathrm{~s}^{48}$, and $7-12 \%$ of the MBM area are

86 permafrost-affected rockwalls ${ }^{49}$. Permafrost is largely present above 2600 and $3200 \mathrm{~m}$ a.s.1. on

87 north- and south-facing slopes, respectively ${ }^{49}$.

88 In the MBM, infrastructures (cable cars, mountain huts, rack railways ${ }^{3}$ ) and mountaineers ${ }^{7}$ are $^{2}$

89 exposed to rockfall. Rockfalls are surveyed since 2007 by a network of observers ${ }^{50}$ focused on the

90 central part $(57 \%)$ of the MBM. First based on the use of reporting sheets, the transmission of

91 information is now done more directly (oral communication, telephone, mail) or by using an app.

92 The network of observers is reactivated annually (through articles, meetings, forums, mailing-lists)

93 while amateur climbers are also solicited through posters installed in huts or articles in the

94 specialized press and forums. During each fall, extensive fieldwork is routinely carried out to

95 verify the observations from the network and/or to complete them with further data. In little-visited

96 areas of the mountain range, fieldwork is carried out at locations that were not reported by the

97 network, but identified by correlative deposits. Finally, for each event, the date of occurrence (or

98 observation of the deposit), the precise location of the scar, topographic parameters of the

99 destabilized area (altitude, orientation, slope), the fallen volume, and an estimate of the depth of

100 detachment are documented.

101 Among all the events inventoried between 2007 and 2015, we selected the 209 rockfalls with all

102 required input data for modeling: coordinates, scar depth, date of failure and MARST (Mean 
Annual Rock Surface Temperature). The MARST was extracted at rockfall locations from the 4-

104 m-resolution map created by Magnin et al. ${ }^{35}$. This map is based on a statistical model calibrated

105 by Boeckli et al. ${ }^{51}$ using MARST measurements from the European Alps, computed potential

106 incoming solar radiation and modeled air temperature.

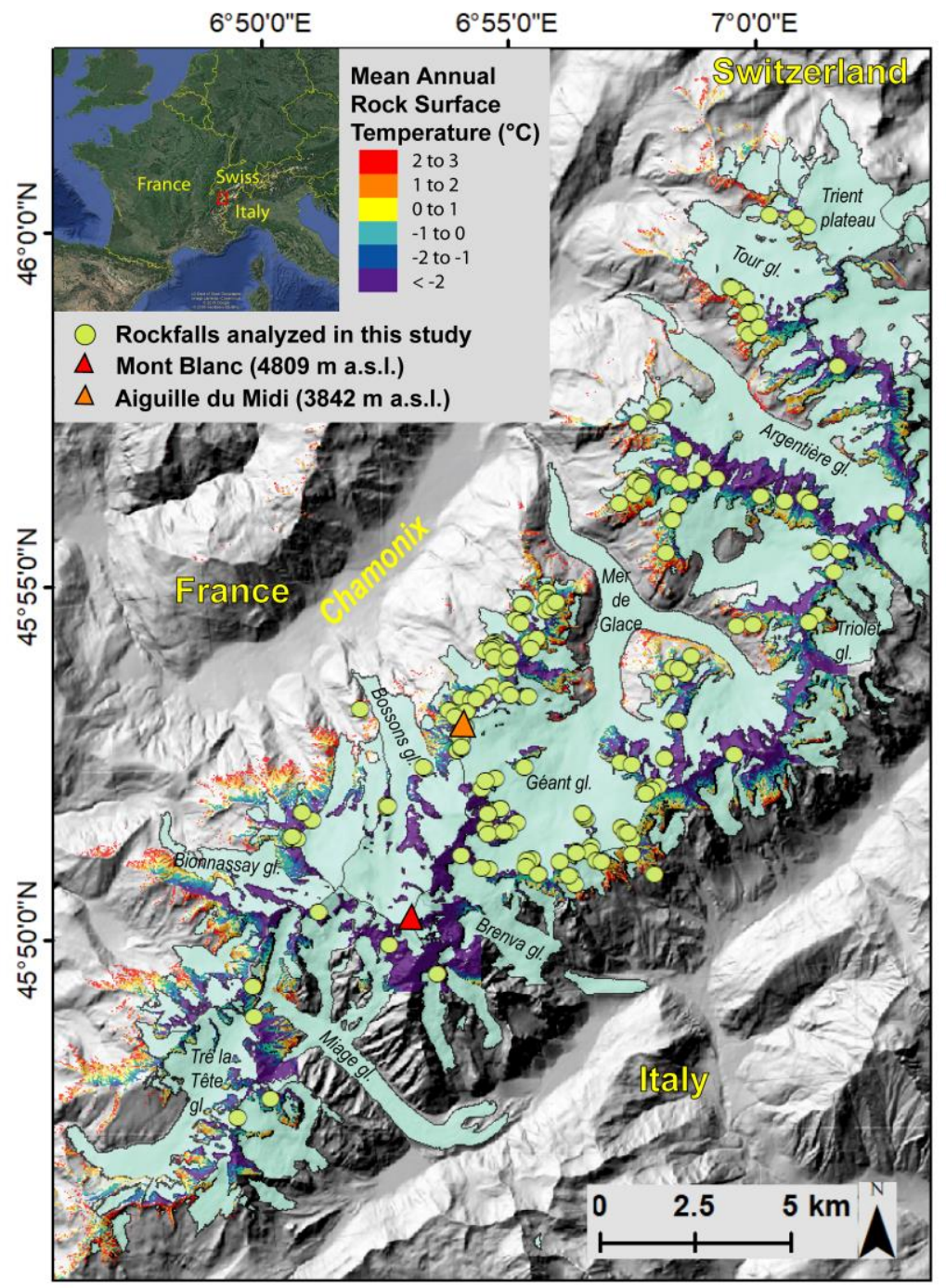

108 Figure 1. The Mont Blanc massif, the MARST distribution and the location of rockfalls analyzed in this study. 
110 Summary characteristics of this rockfall database are displayed in Table 1 and their distribution 111 displayed in Figure 1. The detailed characteristics are provided in Table S1. About 5\% of the 112 rockfalls (10 events) have a MARST $>2{ }^{\circ} \mathrm{C}$, meaning that they are likely in non-permafrost

113 conditions. Indeed, according to Hasler et al. ${ }^{52}$, permafrost might be found below MARST up to

$114 \quad 3{ }^{\circ} \mathrm{C}$ due to the cooling effect of shallow snow cover and air ventilation into fractures. But since 115 the MARST map is built upon mean air temperature for the period 1961-1990 which was about $116 \quad 1^{\circ} \mathrm{C}$ cooler than the recent period ${ }^{35}$, we assume that permafrost may exist below MARST up to $1172{ }^{\circ} \mathrm{C}$. In addition, 23 events $(11 \%)$ have MARST between 0 and $2{ }^{\circ} \mathrm{C}$ and are thus likely in 118 discontinuous and/or warm permafrost conditions.

\section{3. Methods}

121 The goal of our research was to model a temperature-depth $\left(\mathrm{T}_{\mathrm{z}}\right)$ profile at rockfall locations in 122 order to assess the thermal conditions prior to failure. The simulations were conducted in $1 \mathrm{D}$ and 123 intended to represent bedrock temperature perpendicular to the rock surface (Fig. 2). In steep alpine 124 rockwalls, temperature at depth is partly driven by lateral heat fluxes induced by the topographical 125 settings which provoke high surface temperature variability ${ }^{53}$. Thus, we developed an algorithm 126 which accounts for possible lateral heat fluxes in order to correct the modeled $\mathrm{T}_{\mathrm{z}}$ profile. In this 127 section, we introduce the so-called CryoGRID2 model (sect. 3.1) that we used to simulate heat 128 transfer, the forcing data and bottom heat flux correction algorithm (sect. 3.2), the model fitting 129 approach (sect. 3.3), the uncertainty calculations (sect. 3.4), and the model implementation at each 130 rockfall location (sect. 3.5). 


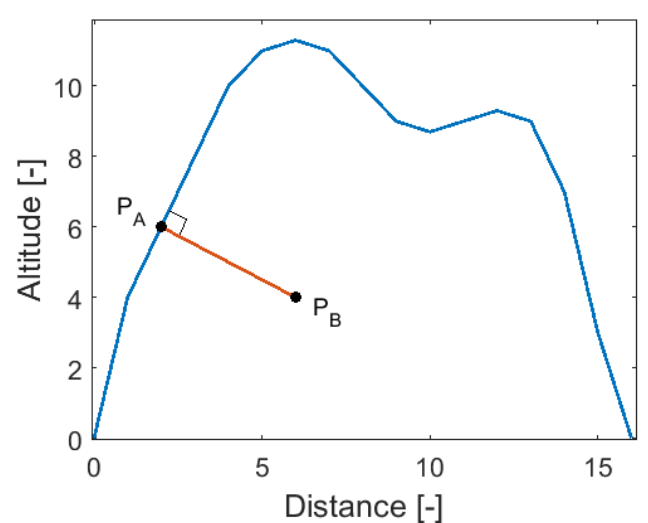

132 Figure 2. Simplified sketch illustrating the modeled $T_{z}$ profiles. The blue line represents a topographical profile. $P_{A}$ 133 is the surface point where the rockfall occurred. $\mathrm{P}_{\mathrm{B}}$ is the bottom point of the profile. The red line is the profile where 134 the temperature was calculated at chosen spatial and temporal steps. Altitude and distance are in arbitrary units.

\subsection{Heat diffusion modeling with CryoGRID2}

137 We used CryoGRID2 for simulating $\mathrm{T}_{\mathrm{z}}$ profiles, a MATLAB diffusive transient thermal 1D model

138 developed by Westermann et al. ${ }^{42}$ solving a nonlinear diffusion equation over time. Initially 139 developed for permafrost issues, it solves the conductive heat transfer by taking into account rock 140 properties, air content, water/ice content, and related thawing/freezing processes through latent 141 heat consumption and release. The top of the profile was forced by a surface temperature time 142 series (Dirichlet condition). At the bottom, the profile was forced by a thermal flux (Neumann 143 condition). At every time step, the profile at time n-1 was used as an input for calculating spatial 144 derivatives. At the first time step, we derived an initialization profile by taking the steady state 145 approximation of the equation with the mean of the surface temperature time series for the 146 Dirichlet condition and the first thermal flux for the Neumann condition. This first thermal flux is

147 derived by assuming that the temperature of the profile bottom is equal to the mean of the surface 148 temperature time series (sect. 3.2). CryoGRID2 can handle snowpack at the rock surface. 149 However, since it is almost impossible to construct or obtain such data in steep alpine rockwalls 
150 where snow depth is highly variable, snow was neglected in the present study. A summary of the

151 CryoGRID2 principal input parameters and outputs are available in Supplements (Table S2).

\subsection{Forcing data and correction heat flux}

154 The top of the $T_{z}$ profiles was forced with Rock Surface Temperature (RST) time series derived 155 from the summation of an air temperature anomaly to the MARST extracted at rockfall locations

156 (sect. 2). The air temperature anomaly was calculated in comparison to the 1961-1990 mean air 157 temperature used to derive the MARST map (sect. 2) and from the daily air temperature recorded 158 by Météo France at Chamonix (1042 m a.s.1.) since 1993 (beginning of hourly air temperature 159 records), similarly to Magnin et al. ${ }^{26}$.

160 We created a correction flux applied at the profile bottom (Neumann condition) to account for 161 possible lateral heat fluxes coming from surrounding rock faces by using the MARST map (Fig. 162 1), the 4-m-resolution DEM used to map the MARST and the Chamonix air temperature anomaly 163 time series. We first searched for all surrounding rock faces that may influence the heat fluxes at $164 \mathrm{P}_{\mathrm{B}}$ (see Fig. 2 for $\mathrm{P}_{\mathrm{B}}$ ) as detailed in the Supplement $\mathrm{S} 1$ to obtained $\mathrm{N}$ points $\left(\mathrm{P}_{\mathrm{i}}\right)_{\mathrm{i} \in[1: \mathrm{N}]}$ at similar 165 altitude than $\mathrm{P}_{\mathrm{A}}$ and which were assumed to influence the lower part of the modeled $\mathrm{T}_{\mathrm{z}}$ profile 166 (Fig. 3). 


\section{Confidential manuscript submitted to PPP}

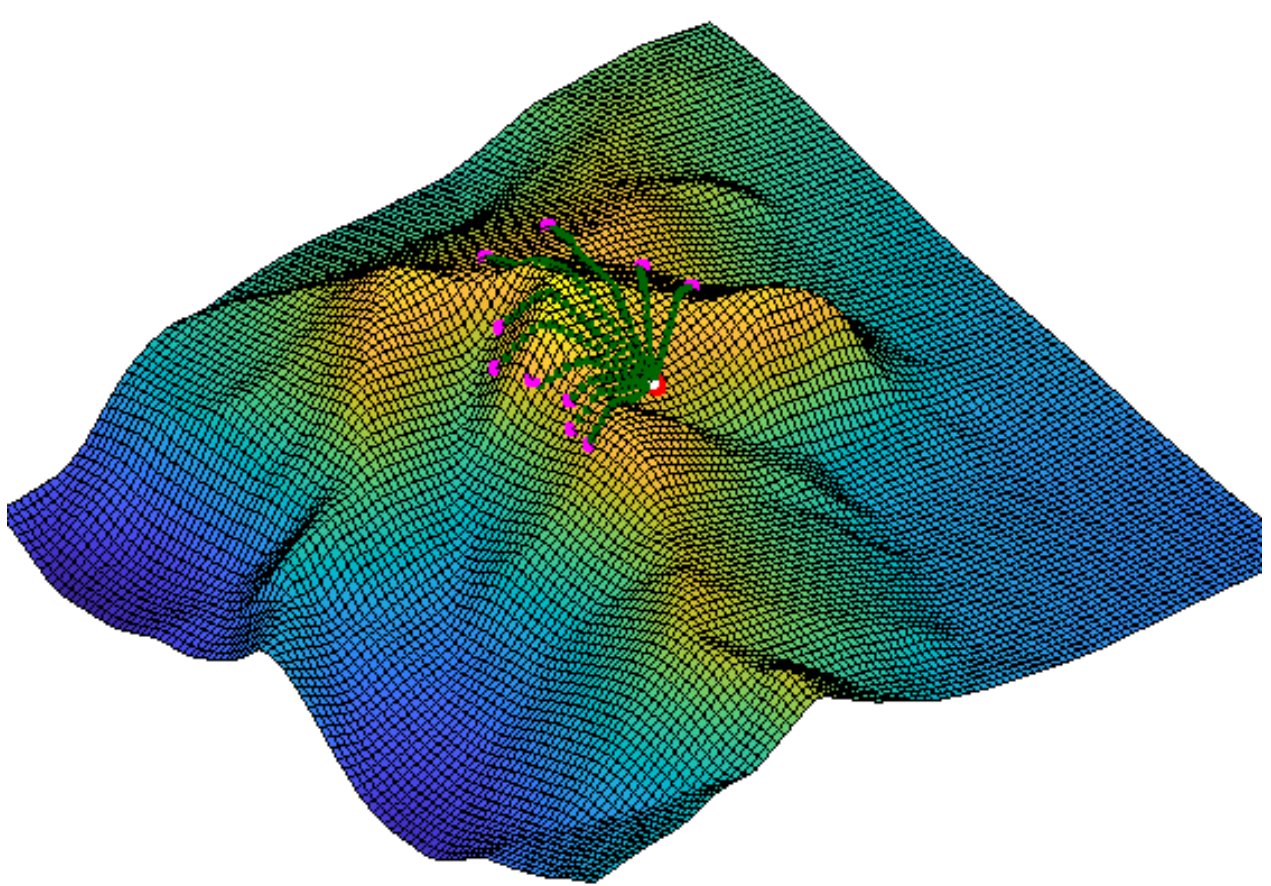

168

169 Figure 3. Illustration of the searching method. The 4-m-resolution DEM is represented on a $200 \times 200 \mathrm{~m}$ square that 170 contains a $200 \mathrm{~m}$ radius circle research limit. The white dot in the center is the surface point $\mathrm{P}_{\mathrm{A}}$ (see Fig. 2 for $\mathrm{P}_{\mathrm{A}}$ )

171 which is the top of the $T_{z}$ profile. The red dots surrounding $P_{A}$ represent all the directions eliminated at the first r-step 172 (see Supplement S1). The green dots represent the research directions. Finally, the magenta dots are the selected points 173 for the correction heat flux calculation. Units and the scale are intentionally hidden to lighten the figure. Likewise, 174 only 20 different directions are plotted (instead of 100 used in this study) to help the readability.

176 We then applied thermal fluxes coming from the selected points. For every point $\mathrm{P}_{\mathrm{i}}$, the MARST 177 at $\mathrm{P}_{\mathrm{i}}$ location $\left(\mathrm{MARST}_{\mathrm{i}}\right)$ is extracted from the map and distance $\mathrm{d}_{\mathrm{i}}$ between $\mathrm{P}_{\mathrm{i}}$ and the bottom point $178 \mathrm{P}_{\mathrm{B}}$ of the modeled $\mathrm{T}_{\mathrm{z}}$ profile was calculated. For calculating the $\mathrm{i}^{\text {th }}$ flux, we separated two cases 179 according to $\mathrm{d}_{\mathrm{i}}(>$ or $<$ to $30 \mathrm{~m})$ as detailed in the Supplement $\mathrm{S} 1$.

180 We thus determined the thermal flux $\mathrm{j}_{\mathrm{Q}, \mathrm{i}}(\mathrm{t})$ of all $\mathrm{P}_{\mathrm{i}}$ and calculated the global $\mathrm{j}_{\mathrm{Q}}(\mathrm{t})$ as follows:

$$
j_{Q}(t)=c_{\exp } \frac{\sum_{i=1}^{N} j_{Q, i}(t)}{100}
$$


181 We divided by 100 because we explored 100 directions, the final flux being an equivalent of a

182 discrete integral. All the fluxes had different directions and different application surfaces. However,

183 we applied all of them at $\mathrm{P}_{\mathrm{B}}$. For considering that, we corrected the final flux by an experimental

184 coefficient $c_{\text {exp. }}$ This coefficient was fitted at the same time as the other model parameters (sect.

$1853.3)$.

186

$187 \quad$ 3.3. Model fitting

188 The simulated transient temperature fields are affected by a set of parameters related to bedrock

189 properties and model characteristics (Table S2). Principal parameters are listed below and have

190 been fitted by running a host of test values until a minimal difference between simulated and

191 measured temperature profiles into boreholes was achieved.

192 - The rock thermal conductivity ( $\mathrm{k}_{\text {bedrock }}$ ), the rock volumetric heat capacity ( $\mathrm{c}_{\text {bedrock }}$ ), the

193 porosity $(\varphi)$ and the total water content $\left(\theta_{\mathrm{w}, \text { tot }}\right)$, which can be assimilated to the bedrock

194 saturation, all change the soil thermal diffusivity, i.e. the time needed for the rock to reach

195 thermal equilibrium.

196 - Van Genuchten parameters (S2) $\theta_{\mathrm{r}}, \alpha$ and $\mathrm{n}$ change the $\left(\theta_{\text {sat }}, \mathrm{T}\right)$ curve. The exact influence is

197 not detailed here but, for example, a higher $\alpha$ will impact the dynamics by requiring a higher

198 temperature for melting all the ice.

199 - $c_{\exp }$ changes the magnitude of the lateral heat fluxes (sect. 3.2). For example, the higher is $c_{\exp }$,

200 the stronger is the cooling effect of opposite north faces on south faces and vice versa.

201 - Spin-up parameters change the accuracy of the results during the first years of simulation. Tests

202 we performed showed that three years of spin-up are enough for limiting errors under $0.1^{\circ} \mathrm{C}$

203 the first year of simulation and that this error quickly decreases over time. 
204 Borehole temperature measurements used for model fitting were collected at the Aiguille du Midi ${ }^{15}$ 205 (ADM; 3852 m a.s.1.; Fig. 1). Three 10-m-deep boreholes have been drilled in 2009 in SE, NE and 206 NW-exposed rock faces with varying slope conditions (55 ${ }^{\circ}$ to sub-vertical) and snow deposits 207 (from continuous and rather thick to discontinuous and thin snow cover, or very local snow 208 deposit). The NE and NW exposed boreholes (respectively BH_E and BH_N) have been equipped 209 with 15 thermistor-chains spread between 0.3 and $10 \mathrm{~m}$ depth, while the SE exposed borehole 210 (BH_S) has 14 sensors spread between 0.14 nd $9.64 \mathrm{~m}$ depth. They have been recording 211 temperature since December 2009 (except BH_E: April 2010) at a 3-hour time interval. Model

212 fitting was performed at a daily time step using temperature time series at the shallowest depths as 213 forcing temperature time series at the top of the model domain. The simulated $\mathrm{T}_{\mathrm{z}}$ profiles were 214 then compared with measured temperatures in the boreholes.

215 Minimization of the Root Mean Square Error (RMSE) between simulations and boreholes time 216 series were obtained with parameter values displayed in Table 2. Figure 4a displays a simulated

$217 \mathrm{~T}_{\mathrm{z}}$ profile for a 9 years period with the best-fitted bedrock properties while Figure $4 \mathrm{~b}$ displays the 218 difference between the measured and the modeled temperature (interpolated between sensors).

219 Figure 5 presents the error distribution obtained with the parameters displayed in Table 2. All the 220 normality tests (Anderson Darling, Kolmogorov Smirnov, Lilliefors...) rejected the hypothesis 221 that this distribution came from a normal distribution at a $5 \%$ significance level. However, the 222 number of points was abnormally high because all the points at every depth and every time were 223 considered in the three cases (more than 5 million points in total). But in reality, there were only 224 three "real" points of comparison (i.e., the three boreholes). The Kolmogorov Smirnov statistic 225 was 0.039 and the critical value corresponding at three data points at a $5 \%$ significance level was 2260.71 , while the critical value with all the points was $10^{-4}$ order of magnitude. Therefore, in this 
227 context of three "real" points of comparison, the test could not reject the hypothesis that the data

228 came from a normal distribution. Thus, for working with Gaussian uncertainties, we assumed this

229 hypothesis of Gaussian errors and we used the mean error of $0.295^{\circ} \mathrm{C}$ and the standard deviation

$230(\sigma)$ of $0.515^{\circ} \mathrm{C}$ (Fig. 5) for our analysis. Based on these results, we systematically removed $0.3{ }^{\circ} \mathrm{C}$

231 (upper bound of $0.295^{\circ} \mathrm{C}$ ) to the final modeled temperatures and a standard deviation value

$232 \sigma_{\text {Cryogrid }}=0.55^{\circ} \mathrm{C}$ (upper bound of $0.515^{\circ} \mathrm{C}$ ) was considered for uncertainty (as a reminder, $\sigma$

233 corresponds to a $68 \%$ reliable level and $2 \sigma$ to a $95 \%$ reliable level for Gaussian data).

234
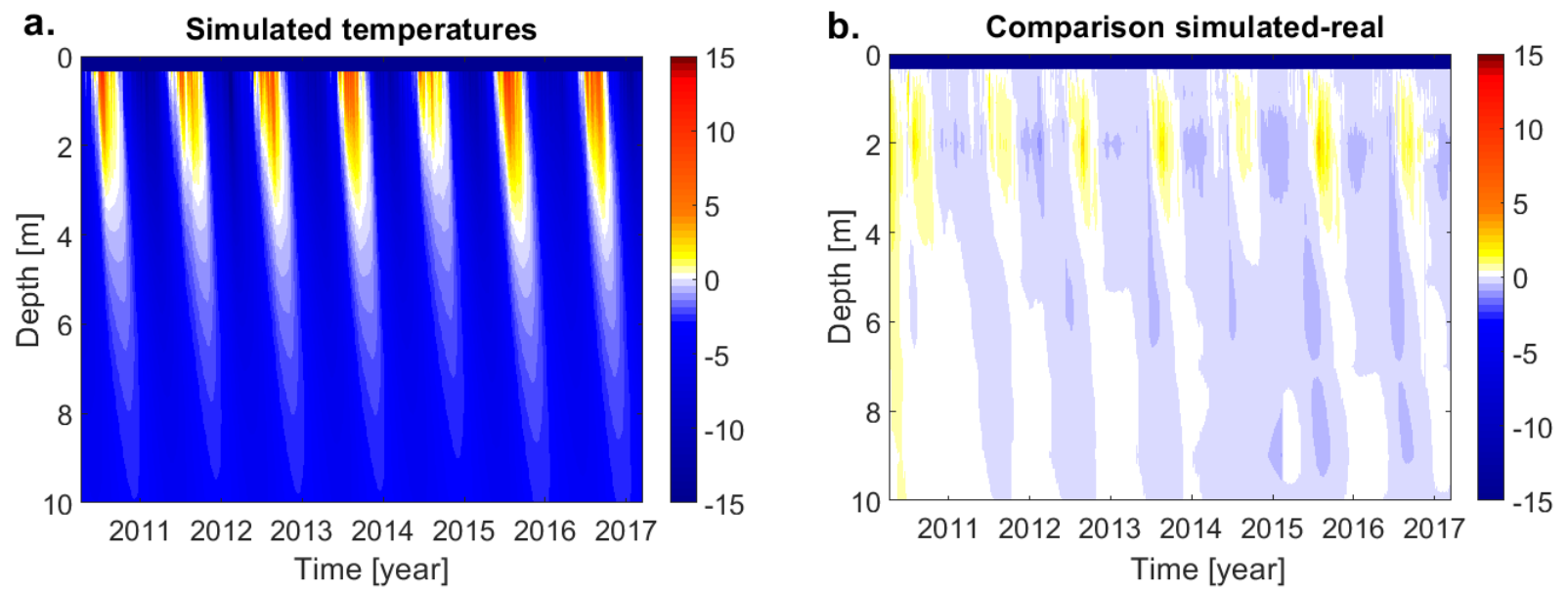

236 Figure 4. a. BH_E borehole simulation realized with parameters detailed in Table 2. Input surface temperatures were

237 extracted from the borehole real values. The $0.3 \mathrm{~m}$ spatial shift at the top of the profiles is due to the depth of the first

238 temperature value recorded in the borehole. b. Comparison between BH_E borehole simulation and real BH_E

239 borehole values. RMSE can then be displaced from these values $\left(\mathrm{e}_{\mathrm{i}}\right)_{\mathrm{i} \in[1: \mathrm{N}]}$ by the following formula: $R M S E=\sqrt{\frac{\sum_{i=1}^{N} e_{i}^{2}}{N}}$. 


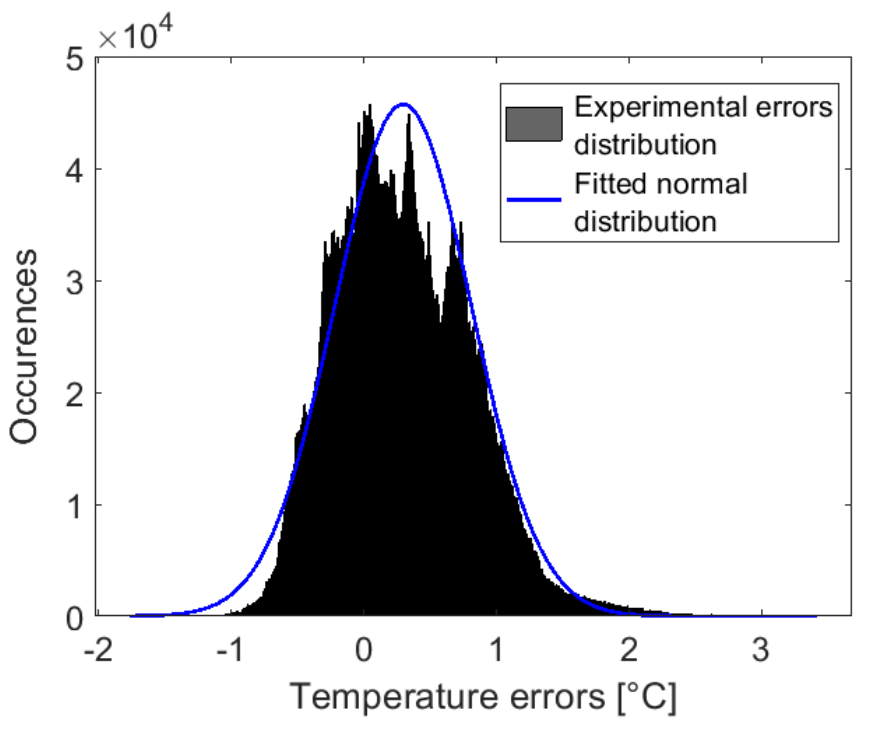

Figure 5. Fit of the temperature errors by a normal distribution. Errors are defined as the difference between the

243 simulated borehole temperatures (BH_S, BH_E or BH_N) and the real borehole temperatures. The fit gave a mean of $2440.295^{\circ} \mathrm{C}$ and a standard deviation of $\sigma=0.515^{\circ} \mathrm{C}$.

246 In addition to the uncertainty associated with model parameters, the uncertainty of the forcing RST

247 time series must be considered. RST time series being created as the summation of a MARST and 248 anomaly values (see sect. 3.2.), we consider two terms for this uncertainty, one for the MARST 249 and one for the anomalies. For the MARST, the standard deviation of $1.616{ }^{\circ} \mathrm{C}$ is reported in the 250 study from Boeckli et al. ${ }^{51}$ that describes the statistical model on which is based the initial MARST 251 used in our study (displayed in Fig. 1). We thus kept the upper bound of this value to determine $252 \sigma_{\text {MARST }}=1.7^{\circ} \mathrm{C}$. For the anomalies, the uncertainty results from the only consideration of the air 253 temperature changes in Chamonix to create RST anomalies while daily RST variations may also 254 result of the varying lapse rate, which is typical of alpine environments ${ }^{54}$, as well as the varying 255 incoming solar radiation and possible snow accumulation ${ }^{49}$ which are neglected. We calculated 256 the uncertainty for RST anomalies, referred as $\sigma_{\text {anomaly }}$, by using a set of measured RST time series 
257 at 5 sensors installed at the top of the ADM in sub-vertical S (2 sensors), N, E, and W exposed 258 rock faces, at a depth of $0.03 \mathrm{~m}^{49}$.

259 One of the two S-exposed sensors is located right above a ledge where snow accumulates during 260 winter which lowers the MARST by about $1^{\circ} \mathrm{C}$ compared to snow-free conditions for similar sun261 exposure $^{49}$. RST have been recorded continuously at an hourly time step from 2007 to 2010 . The 262 MARST for the years 2007 to 2010 were then calculated for each sensor and were adjusted to the 263 1961-1990 period by applying the air temperature anomaly between 1961-1990 and the years of 264 measurements (2007 to 2010). Then, the adjusted MARST of each sensor was subtracted to the 265 measured daily RST to obtain daily temperature anomalies at sensor locations.

266 Comparison between the daily air temperature anomalies measured in Chamonix and the RST 267 anomalies calculated from the 5 RST sensors resulted in Gaussian errors with a standard deviation 268 of $\sigma_{\text {anomaly }}=4{ }^{\circ} \mathrm{C}$.

269 To sum up, the uncertainties were as follows:

$270 \quad-\sigma_{\text {Cryogrid }}=0.55^{\circ} \mathrm{C}$

$271 \quad \bullet \quad \sigma_{\text {MARST }}=1.7^{\circ} \mathrm{C}$

$272 \quad-\sigma_{\text {anomaly }}=4{ }^{\circ} \mathrm{C}$

273 Then, for surface temperature series, the total uncertainty was:

$$
\sigma_{\text {surf }}=\sqrt{\sigma_{\text {MARST }}^{2}+\sigma_{\text {anomaly }}^{2}}
$$

274 Numerically, it gave: $\sigma_{\text {surf }}=4.4{ }^{\circ} \mathrm{C}$.

275 In the next part of the study, the temperature at the depth of the rockfall scar was analyzed (referred 276 hereafter as "scar temperature"). With most scar depth > $1 \mathrm{~m}$ (Tab. 1), these temperatures were not 277 significantly affected by daily surface temperature changes. Thus, $\sigma_{\text {anomaly }}$ was neglected when 278 dealing with scar temperatures and total uncertainty for scar temperature was therefore: 


$$
\sigma_{\text {scar }}=\sqrt{\sigma_{\text {Cryogrid }}^{2}+\sigma_{\text {MARST }}^{2}}
$$

279 Numerically, it gave: $\sigma_{\text {scar }}=1.8^{\circ} \mathrm{C}$.

To analyze the results, we also used temperature percentiles (sect. 4). A X \% temperature

281 percentile is defined as a value which is warmer than $\mathrm{X} \%$ and colder than $(100-\mathrm{X}) \%$ of some

282 chosen reference temperatures which were defined as explained in section 4. To estimate modeled

283 temperature percentile uncertainties, simulations were done for the three boreholes, using the

284 MARST map (Fig. 1) and the air temperature anomaly to generate the forcing surface temperature

285 time series. Percentiles of the modeled temperature values were then calculated for the full 286 borehole time series and compared with the real temperature percentile values. Gaussian errors

287 were obtained, with $\sigma_{\text {surf prct }}=13.8 \%$ and $\sigma_{\text {scar prct }}=10.7 \%$. This approach of considering all the 288 uncertainty sources at once was less precise but sufficient in that case with long and complex 289 calculations.

\subsection{Approach for simulating the temperature dynamics at rockfall locations}

To analyze bedrock thermal dynamics prior to rockfalls, the following protocol was used

293 for every event:

294 - The rock surface temperature time series was created as described in section 3.2.

295 - The CryoGRID2 simulations were run between $1^{\text {st }}$ January 1993 and $31^{\text {st }}$ December 2015, with the bedrock parameters determined after fitting (Tab. 2). Given that the fitting step showed that a spin-up period of 3 years is sufficient, we assumed that the years 1993-1996 were the spin-up years while rockfalls are only documented since 2007 . The simulated $T_{z}$ profiles were $20.5 \mathrm{~m}$ long, which is $5 \mathrm{~m}$ deeper than the deepest scar depth (Tab. 1). This 
$5 \mathrm{~m}$ buffer permitted to lower the errors in the deeper part of the profiles where the correction thermal flux was applied (see sect 3.3).

302 This process was entirely automated in Bash language and MATLAB programs on the Univ.

303 Savoie Mont Blanc - CNRS/IN2P3 MUST computing center. Then, all the simulations could be

304 started at the same time on different calculation resources.

\section{4. Approach for result analysis}

\subsection{Model output processing and analysis}

308 Four rock temperature variables were analyzed: the (i) scar and (ii) surface temperatures, and the

309 (iii) scar and (iv) surface temperature percentiles. They were all examined through 11 different 310 temporalities: 1 day, 3 days, 5 days, 1 week, 10 days, 2 weeks, 17 days, 3 weeks, 1 month, 45 days

311 and 2 months. The surface temperature was simply extracted at the uppermost depth of the $\mathrm{T}_{\mathrm{z}}$

312 profile $(0.05 \mathrm{~m})$. The scar temperature was extracted at the scar depth specified in the rockfall

313 database for each event (Tab. 1). For temporality of 1 day, surface temperature percentiles were

314 calculated by comparing the simulated surface temperature at the day of rockfall occurrence with

315 all the daily surface temperatures of the simulated time series $\left(1^{\text {st }}\right.$ January $1996-31^{\text {st }}$ December

316 2015). For other temporalities of $n$ days prior to rockfall occurrence, the reference temperatures

317 were calculated by averaging the temperature between a day $d l$ which is, by turns, each day in the

318 temperature time series, and a day $d 0$ which is the first day of the averaging period prior to $d l$,

319 defined as $d 0=\mathrm{d} 1-n+1$. Then, the average temperatures for the various temporalities prior to

320 failure were compared with the respective reference temperatures. At this step, we had only

321 absolute values of surface and scar temperatures, and absolute values of surface and scar 
322 temperature percentiles. We then aimed at answering if this temperature value was abnormally

323 high for the current period.

324 To do so, 1000 dates were drawn randomly and the 4 studied variables were extracted for the 11

325 different temporalities at each rockfall location. The choice of the number of random events was

326 based on a compromise between the calculation resources and the potential to reduce the

327 uncertainty. The scar depths of the 1000 random dates of a specific event location were chosen

328 equal to the scar depth of this event. To remove sources of biases, dates of the random events were

329 drawn: a) after 2007 and b) with the same monthly distribution as the 209 rockfalls events. Reason

330 for a) was to remove biases linked to the recent decades of atmospheric warming as the rockfall

331 database starts in 2007. If artificial rockfall events would have been drawn in the full period 1996-

332 2015, extracted temperatures at the beginning of the time series would have been expected to be

333 lower and it would have been impossible to determine if a significance of warmer temperatures

334 for rockfall events was real or just related to the atmospheric warming contribution. Reason for b)

335 is that rockfalls mostly occurred between June and October (with an attendance peak in August,

336 Fig. 6a) and these months were, on average, warmer than other months of the year. If random

337 events would have been drawn in the full year, a significance of warmer temperature for real events

338 could have been simply interpreted as the reflection of this reason and not as an extraordinary

339 thermal state of the rock before the failure. Thus, random events were drawn according to the same

340 monthly distribution as the 209 real events (Fig. 6a). Figure $6 \mathrm{~b}$ shows that the temporal distribution

341 of rockfall events is not dependent on the scar depth, that is why the same monthly distribution is

342 taken for every scar depth and that no scar depth groups were created. Likewise, no relationship

343 was found with the elevation, the slope angle or the sun-exposure (Fig. S1). 


\section{Confidential manuscript submitted to PPP}

a.

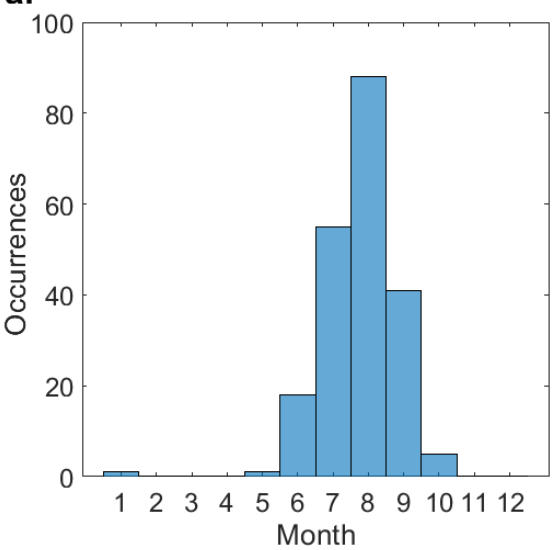

b.

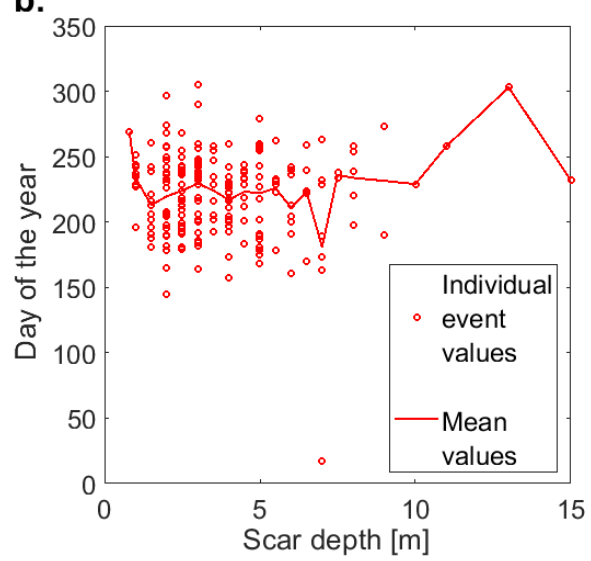

346 Figure 6. a. Histogram illustrating the distribution of the 209 rockfalls throughout the year that was used as a basis to

347 draw random events dates. b. Plot illustrating the distribution of the events throughout the year in comparison to the

348 scar depths. The absence of relationship between scar depth and rockfall timing was considered to not draw the

349 monthly distribution of random events according to depth. The same is true for elevation, slope angle and sun-exposure

350 (Fig. S1). Means of $0.8 \mathrm{~m}, 9 \mathrm{~m}, 10 \mathrm{~m}, 11 \mathrm{~m}, 13 \mathrm{~m}$ and $15 \mathrm{~m}$ scar depths must be observed carefully because they are

351 represented by one or two points only.

\subsection{Determining results significance}

354 For searching significant results, real rockfalls temperatures and temperature percentiles were 355 compared with those of random events. Firstly, a simple comparison of the means for every scar 356 depth and every temporality was realized. Then, the comparison was done for every temporality 357 without regarding the scar depth. Uncertainties were derived by dividing the uncertainty of the 358 variable $\left(\sigma_{\text {surf }}, \sigma_{\text {scar }}, \sigma_{\text {surf prct }}\right.$ or $\left.\sigma_{\text {scar prtt }}\right)$ by the square root of the total number of points used for 359 calculating the mean. Since 209000 random events were considered, uncertainties of the means

360 of random events variables were small and almost impossible to see when plotted against the real events uncertainty. 
362 A Kolmogorov Smirnov test (KS test) was then performed for assessing if the real rockfalls sample

363 could have been drawn from the random events distribution. It was calculated by determining the

364 highest ordinate difference between the Cumulative Distribution Functions (CDFs) of the real

365 rockfalls and the random events series. This statistic was then compared with tabulated critical

366 values for obtaining the result of the test. This test was chosen because it is non-parametric, which

367 is important since the temperature percentiles are clearly not Gaussian (Anderson Darling,

368 Kolmogorov Smirnov and Lilliefors tests reject this hypothesis with a $5 \%$ significance level), and

369 because it was possible to consider the uncertainty values while performing the test. This second

370 point is, astonishingly and unfortunately, uncommon for statistical tests. The only feasible rough

371 uncertainty incorporation is generally to present upper and lower bounds of the test by realizing it

372 with the high and low values of the data points. Here, for surface or scar temperature percentiles,

373 the uncertainties were included as explained in the Supplement S2.

374 An example of CDF represented with the uncertainties and resulting KS test is displayed in Figure

3757 for one specific variable (surface temperature percentile) and one specific temporality (1 day).

376 The KS statistic must be compared with the critical value (cv). If the statistic is higher, the test

377 rejects the hypothesis that the experimental data (real events) comes from the model (random

378 events) with a $5 \%$ significance level. Here, the test rejected the hypothesis that the experimental

379 data (real events) came from the model (random events) in the normal case with a $5 \%$ significance

380 level, but could not reject this hypothesis when considering the uncertainties. 


\section{Confidential manuscript submitted to PPP}

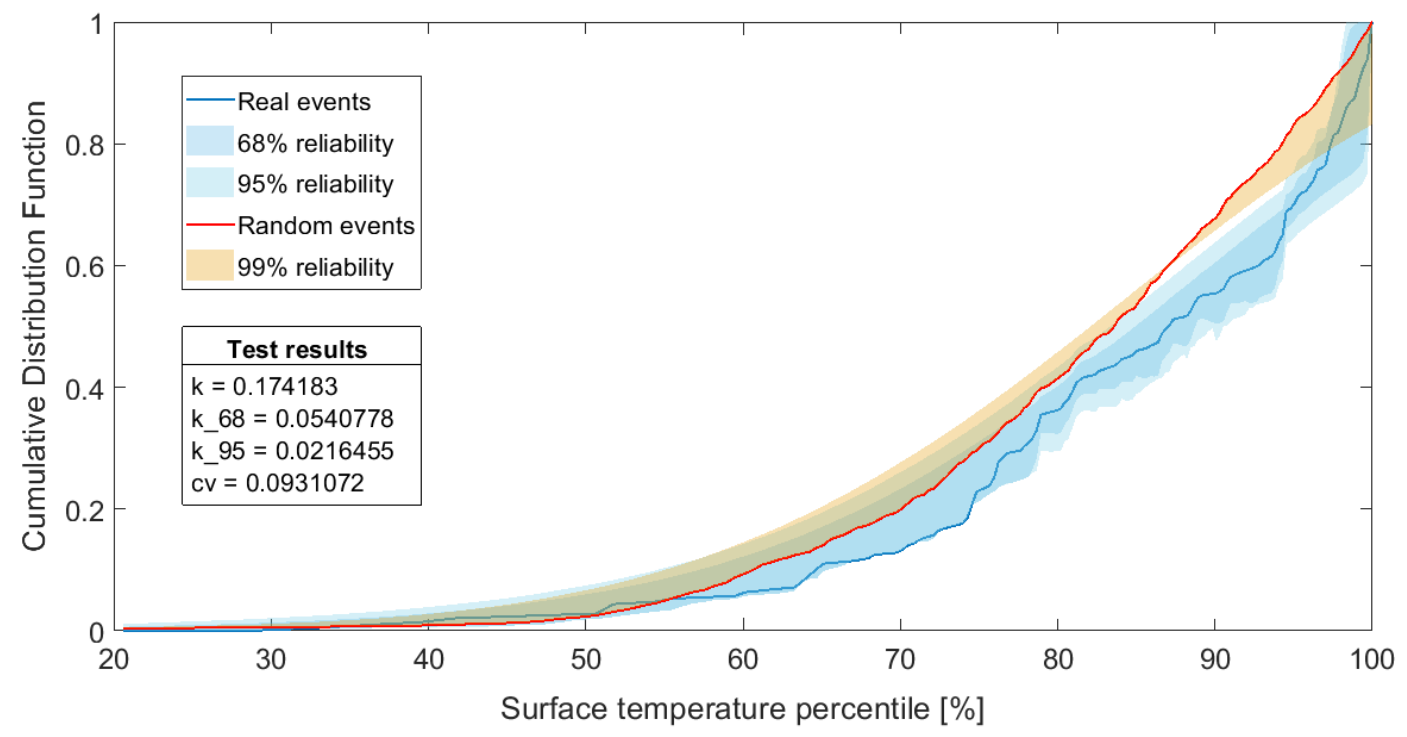

Figure 7. Illustration of a KS test result. The surface temperature percentiles were here considered at the rockfall 383 event day (temporality of 1 day). " $\mathrm{k}$ " represents the KS statistic between the CDFs without considering the

384 uncertainties. "k_68" represents the statistic between the $68 \%$ reliable real events CDF and the $99 \%$ reliable random 385 events CDF. "k_95" represents the statistic between the $95 \%$ reliable real events CDF and the $99 \%$ reliable random 386 events CDF. The $68 \%$ and $95 \%$ reliable random events CDFs are not presented because they were very close to the $38799 \%$ reliable one (the reason for this stability is that random events CDF is made of 209000 points). "cv" is the $5 \%$ 388 significance level critical value of the KS test in this context. To know the result of the test, the KS statistic must be 389 compared with the critical value. If the statistic is higher, the test rejects the hypothesis that the experimental data (real 390 events) come from the model (random events) with a $5 \%$ significance level. Here, the test rejected the hypothesis in 391 the normal case but could not reject it when considering the uncertainties.

393 To show orders of magnitude of simulated temperatures, scar and surface temperature variables 394 were used in a first step. However, in a second step, only temperature percentile variables were 395 kept since they are better for finding statistical significance. 


\section{Results}

When considering the uncertainties, none of the four variables (surface and scar depth

400 temperatures and temperature percentiles) could be distinguished from the random events values

401 when reasoning by scar depth. This finding is illustrated in Figure 8 for a temporality of 1 day

402 while other temporalities, showing similar patterns, are displayed in the Supplements (Fig. S2).

403 However, whatever the considered variable, the mean distributions were in most cases - except 6

404 and $7 \mathrm{~m}$ depths - higher than the random events. This was particularly pronounced for the

405 percentile variables. The four variables were strikingly scattered, but some notable patterns could

406 be distinguished. First, the closer to the surface, the warmer was the scar temperature, for both real

407 and random events. The average temperature became negative from 3-4 $\mathrm{m}$ depth downward (see

408 Fig. S2 also) but consistency in negative scar temperature was found for depths $>6 \mathrm{~m}$ only, despite

409 a few events showed positive and close to $0{ }^{\circ} \mathrm{C}$ conditions. Only 2 events had scar temperature <

$410-5{ }^{\circ} \mathrm{C}$. The surface temperatures were mostly positive and no distinct pattern could be found

411 according to scar depths. Scar temperature percentiles scattering increased with depth and their

412 mean decreased from 90 to $50 \%$ between 1 and $9 \mathrm{~m}$ depth while surface temperature percentiles

413 showed no obvious link with scar depths. When extending the temporalities (Fig. S2), very similar

414 patterns were found, with slightly smaller scattering, slightly higher surface percentiles and 415 slightly lower scar temperature percentiles. 


\section{Confidential manuscript submitted to PPP}
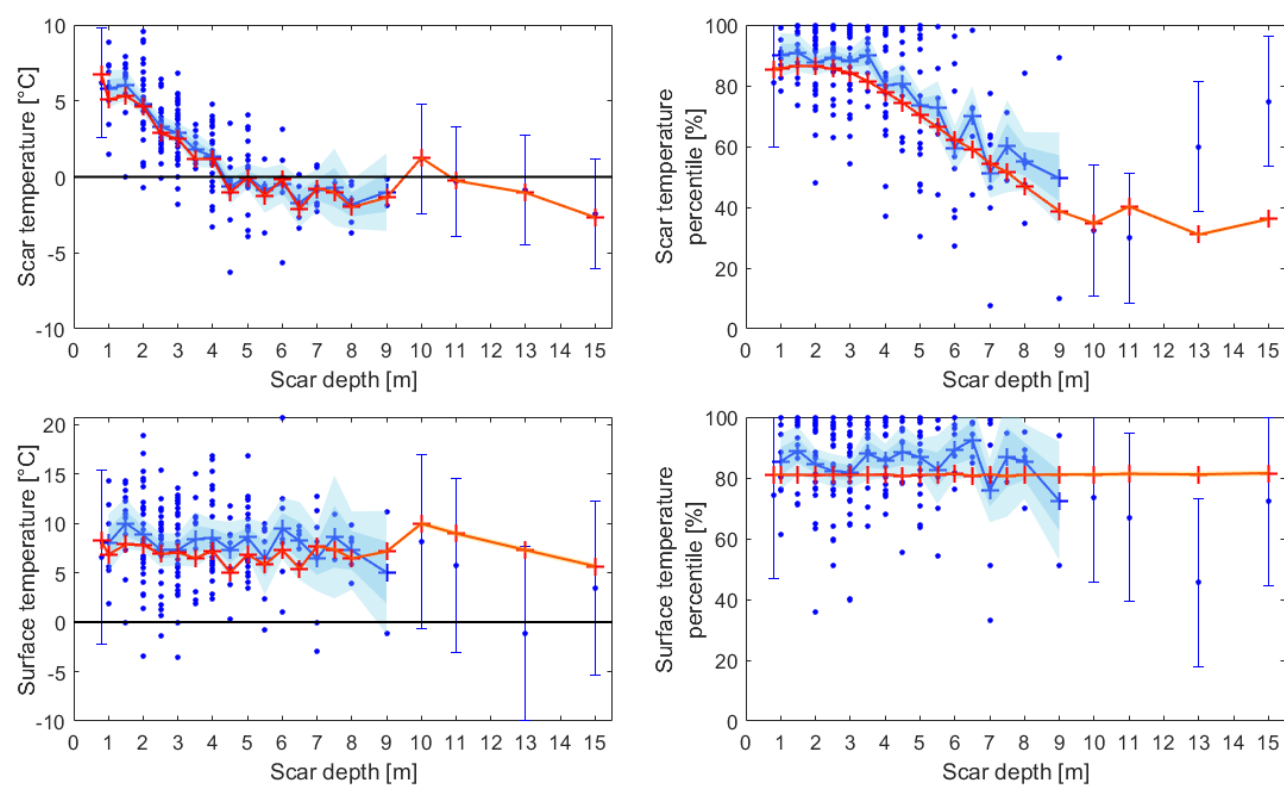

- Real events

- Real events with $\Delta_{95 \%}$

+ [Mean] Real events [Mean] 68\% reliability [Mean] 95\% reliability +- [Mean] Random events [Mean] 68\% reliability [Mean] 95\% reliability

Figure 8. Comparison of the four studied variables between real and random rockfalls on the day of the event

419 (temporality of 1 day). This comparison was done for every scar depth, all the events with the corresponding value of

420 scar depth being used for calculating a mean. Ten other groups of figures like this one were done to verify our results

421 for the 10 other temporalities (3 days, 5 days, 1 week, 10 days, 2 weeks, 17 days, 3 weeks, 1 month, 45 days and 2

422 months) and four of them (1 week, 2 weeks, 1 month and 2 months) are presented in the Supplements (Figures S2).

423 Uncertainties of random events variables cannot be seen because they were really low (order of magnitude of some 424 degree tenths for temperature variables and some percent tenths for temperature percentile variables).

426 When looking at the results through the different temporalities, percentiles of scar and surface 427 temperatures were, distinctively higher than the random events values, whatever the temporality 428 (Fig. 9). For scar temperature percentiles, this difference was in order of magnitude of $3 \%$ for 429 mean values and at least $1.5 \%$ for $95 \%$ reliability values. For surface temperature percentiles, these percentages were nearly equal to 2.5 and $0.5 \%$. 


\section{Confidential manuscript submitted to PPP}
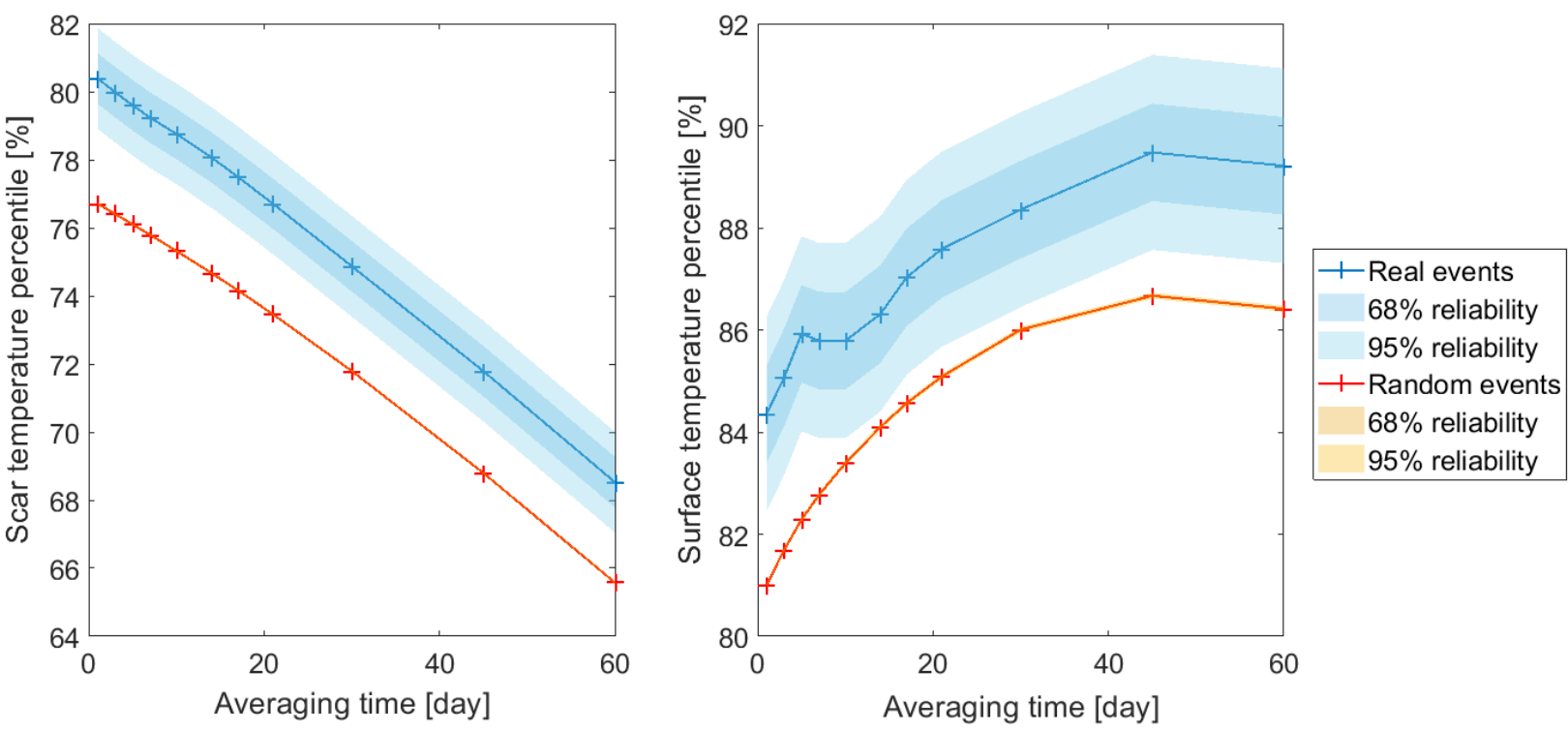

433 Figure 9. Comparison of the average temperature percentile variables between real and random rockfalls. Here, all 434 scar depths were merged which explains a constant and rather low uncertainty (individual uncertainty divided by the 435 square root of the total number of events, 209 for the real ones and 209000 for the random ones). Every single point 436 of this represents a full plot of Figure 8.

438 Implementation of the KS test showed that scar temperature percentiles for real events were 439 significantly different from random events for temporalities between 1 and 21 days (Fig. 10). This 440 significance decreases almost continuously with increasing temporality. Surface temperature 441 significances varied with the different temporalities but were always well above the critical 442 threshold. It reached its minimum value at about 14 days averaging time prior to failure and then 443 increased continuously until 45 days averaging time prior to failure where it reached its maximum 444 value. However, when considering the uncertainty, these results were not significant and it was 445 therefore not possible to state whether the real events sample could have been drawn from the 446 random events distribution. This points out the interest to work with a greater number of rockfalls. 


\section{Confidential manuscript submitted to PPP}

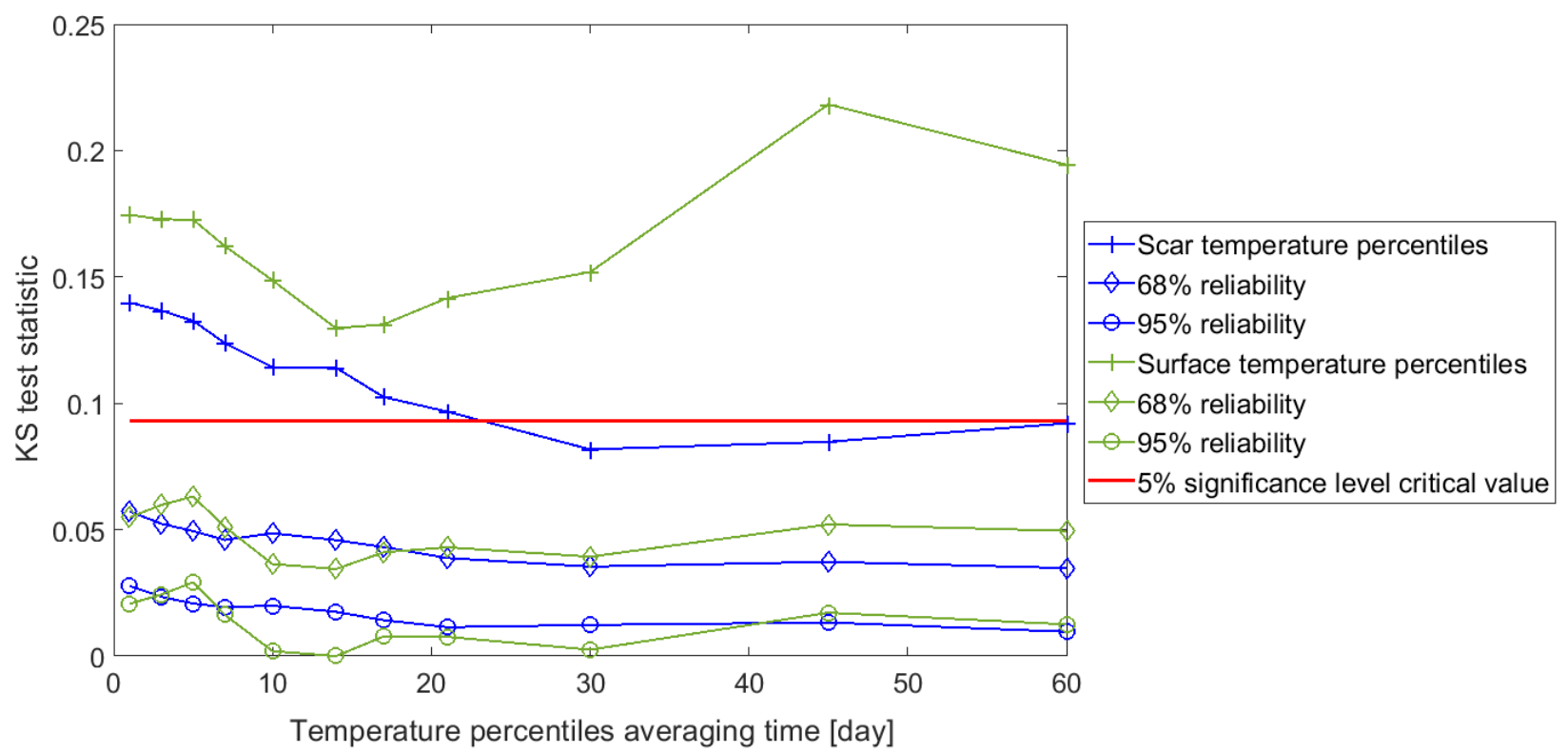

Figure 10. Illustration of the significance of scar and surface temperature percentiles for every temporality. Every

449 point of this plot corresponds to a KS test. For example, the three values "k", "k_68" and "k_95" calculated in Figure 4507 are here represented by the green triplet of points (plus-sign marker, diamond marker and circular marker) at the 1451 day abscissa.

\section{6. Discussion}

\subsection{Strengths and limitations of the study}

455 For this study, we have used a homogeneous rockfall inventory which ensures direct comparability 456 of the results and a coherent statistical analysis. The relatively simple thermal modeling approach 457 may appear as the main limitation since it lacks of consideration for solar radiation variability 458 through time, precipitations and wind effects, or snow deposit controls. Energy balance approaches

459 which have been commonly used in rockwall permafrost modeling ${ }^{19,55-57}$ would allow overcoming 460 some of these limitations. However, by introducing a greater number of input parameters, energy 461 balance models bear numerous sources of uncertainty, challenging its quantification ${ }^{58}$. In this way, 462 our simple modeling approach combined with the availability of bedrock temperature data into 
463 boreholes has the main advantage to permit a detailed uncertainty analysis of our results. In 464 addition, our approach accounts for most important parameters which are an average value of 465 incoming short-wave solar radiation and air temperature (for the MARST calculation ${ }^{59}$ ) at the 466 bedrock surface and the heat conduction at depth. Nevertheless, bedrock thermal parameters 467 (conductivity and heat capacity) have been calibrated with borehole temperature measurements 468 collected in the granitic part of the MBM while $18(8.6 \%)$ of the rockfalls occurred in the 469 metamorphic series. But since these series have in most cases very similar mineral composition as 470 the granitic unit ${ }^{47}$, it is assumed that the results are marginally impacted, the variable anisotropy 471 which is not only related to lithology but also to site-specific fracturing possibly being the most 472 critical issue.

473 Another limit lies in snow deposits that may cool the bedrock surface and delay the thawing onset 474 during warm seasons ${ }^{57,60}$ when some rockfalls occurred. Thus, the greater statistical significance 475 of rather long time period of high surface temperature prior to rockfalls may partly depict the time 476 needed for snow melt for some events. But, in parallel, snow melt or rainfalls could also accelerate 477 the thawing through water percolation into bedrock fractures ${ }^{30,32}$. The only possible reflection of 478 this overlooked effect in the results would be the events with rather low scar temperature 479 percentiles right before failure (Fig. 8). This means that the bedrock temperature didn't reach its 480 highest value when the failure occurred suggesting either that sudden heating is not the main 481 triggering factor or that other processes such as heat advection may have locally accelerated 482 bedrock warming. Such accelerated bedrock thawing was already suggested by former studies ${ }^{19,37}$ 483 to explain permafrost-related rockfalls. Despite these limits, our results allow discussing possible 484 thermal processes triggering rockfalls according to scar depth and climate signal characteristics. 485 


\section{The role of thermal processes in rockfall triggering}

488 Variables comparison with scar depths (Fig. 8) has shown that it would have been irrelevant to 489 analyze the results based on scar depth groups. Such an analysis could have been attractive since

490 it could have been expected that scar temperature significance would have overweighted the one 491 of surface temperature. But the constantly low difference between random and real events

492 variables shows that the observed pattern is not specific to the real events and that the supposedly 493 link between scar depth and bedrock temperature pattern must be seen as the depiction of general 494 thermal conditions at rockfall locations. The decreasing average in scar variables (Fig. 8) must be 495 seen as the expected depth effect involving a delayed response to climate signals.

496 Temperature values at scar depths discriminate possible rockfall triggering processes with 497 permafrost degradation or frost-related processes strongly suggested for events $>6 \mathrm{~m}$ and for a 498 significant part of shallower events (3 to $6 \mathrm{~m}$ ). On average, these events occurred in a range of 499 temperature between 0 and $-2{ }^{\circ} \mathrm{C}$ and show noticeable agreement with experimental and theoretical 500 knowledge about reduced shear strength of ice-filled fractures within this temperature range ${ }^{24,27}$. 501 In mountain environments, rockwalls are prone to instability because of extreme conditions with 502 large and sometimes sudden temperature variation, freeze and thaw cycles, as well as wet and dry 503 cycles throughout the year ${ }^{29,61-64}$. Frost weathering processes related to ice segregation and 504 volumetric expansion, as well as repeated freeze and thaw cycles leading to bedrock fatigue are 505 well recognized mechanisms preparing to bedrock failures by breaking rock bridges and favoring 506 fracture propagation ${ }^{61,65-67}$. Similarly, high thermal stress related to strong thermal oscillations is 507 also regarded as an essential factor favoring bedrock cracking due to repeated thermal contractions 508 and expansions that also affect non-periglacial rockwall, the warm days being particularly prone 
509 to rockfall occurrence $39,40,68,69$. The fact that many shallow events occurred at positive rock

510 temperature but also well higher than average rock temperatures as suggested by the temperature

511 percentiles, corroborates those studies.

512 In addition to the interpretation of possible processes acting in rockfall, percentiles reveal how air

513 temperature signals contribute to their triggering. Indeed, temperature values are suited for an

514 intrinsic comparison of the rockfall sample elements, while temperature percentiles rather inform

515 about the thermal dynamics specific to each location of the rockfall sample elements. In addition,

516 percentiles are better suited for determining statistical significance.

518 Link between air temperature signals and rockfall triggering

519 Comparisons of percentile means (Fig. 9) show that the real events have, in average, a warmer 520 temperature condition prior to failure than random ones, whatever the considered temporality, 521 from 1 day to 2 months (Fig. 8 and S2). However, the difference between the real rockfall events 522 and the random rockfall events can also be a statistical "sample effect" and the questions of 523 whether and to what extent the sample could have been drawn from the model persist. This 524 question is answered by the KS test and the significance study (Fig. 10). In the following, a high 525 significance must be interpreted as an approval of the previous results, namely that the real events 526 show warmer temperature conditions than usual and that this difference is not due to a "sample 527 effect". The results show that the surface temperature percentiles between 1 day and 2 months 528 prior to failure are significantly higher than usual. More specifically, the highest significance for 529 these exceptionally high surface temperature percentiles is found 1.5 to 2 months prior to failure 530 and, in to a lesser extent, at an early time prior to the rockfall ( 1 to 5 days). In between these early 531 and late time periods, the statistical significance for the surface temperature percentiles decreases 
532 and reaches a minimum at 2 weeks. This suggests that rockfall occurrences are favored by long-

533 lasting heatwaves (i.e. extended period of unusually high atmospheric heat) overtopped by a hot

534 spell (one or a few days of intense heat ${ }^{70}$. This early compound can thus be interpreted as a

535 triggering effect which only reinforces a long-term high surface temperature signal. The late

536 compound becomes more relevant in relation to the statistical significance of the scar temperature

537 temporalities. Indeed, high significances of scar temperatures for short time period $(<20$ days $)$ are

538 in some ways a corollary of high percentiles of surface temperature for at least a month due to the

539 delay needed for heat diffusion. But this would mean that bedrock failures are somewhat a direct

540 response to extraordinary high temperature at depth. Such results are partly in agreement with the

541 findings from Luethi et al. ${ }^{37}$. This last study found that mid-sized rockfalls such as those we

542 investigated are a direct response to short-term periods of high surface temperature. The authors

543 attribute this fast reaction to accelerated bedrock thawing provoked by advective heat transfer from

544 water percolation. While this study was not accounting for the thermal dynamics at scar depth, our

545 study shows that scar depths were also affected by exceptionally high temperatures which are

546 explained by the only effect of heat conduction. It further demonstrates that this high temperature

547 at scar depth is likely a response to several weeks or months of high bedrock surface temperature.

548 It does not exclude effect of advective heat transport but suggests that heat conduction exerts a

549 predominant control. Such findings somehow remind the findings from Paranunzio et al. ${ }^{36}$ which

550 pinpointed warm air temperature anomaly associated with a majority of rockfalls observed in the

551 Western Italian Alps. Finally, similarly to the study of Luethi et al. ${ }^{37}$, it confirms that other thermal

552 processes than permafrost degradation are probably responsible for small size rockfalls,

553 supposedly high thermal stress due to intense temperature variation favoring bedrock failure

554 preparation. 
555 These interpretations must be considered with caution since they are based on findings for which

556 the significance cannot be confirmed when considering the modeling approach uncertainty. This

557 limit draws some research outlooks that could lead to the definition of a susceptibility index of a 558 rockfall to occur according to the weather forecast.

561 Our study has shown that when considering model uncertainty, a part of our interpretation loses

562 significance as it is not clear whether the same results could have been drawn from a random 563 sample. For lowering these uncertainties and confirming/improving these results, two solutions are 564 possible.

565 The first one, which is the most challenging, is to lower the modeled temperature uncertainties 566 ( $\sigma_{\text {Cryogrid }}, \sigma_{\text {MARST }}$ or $\sigma_{\text {anomaly }}$; see sect. 3.5). $\sigma_{\text {Cryogrid }}$ could be improved by getting other borehole 567 data in order that CryoGRID2 parameters better represent the study area (boreholes in rockwalls 568 with other characteristics or in the metamorphic basement for example). $\sigma_{\text {MARST }}$ could be tackled 569 by modeling the MARST with a RST sample collected in the study area rather than across the 570 entire European Alps ${ }^{35,51}$. Finally, $\sigma_{\text {anomaly }}$ could be improved by better defining the daily surface 571 temperature (see sect. 3.2.). RST anomaly time series could be created at the specific rockfall 572 locations by combining different meteorological parameters in a well-constrained energy balance 573 model.

574 The second solution for lowering the uncertainties would be to increase the sample size with a 575 higher number of rockfalls. This would lower the KS test critical values and the CDF uncertainties. 576 This second solution would be considered in the near future as the rockfall database will be 577 enriched with more recent events (2016-2020) which are currently under processing. 
578 Additionally, with the method described in sect. 4, atmospheric warming and seasonal biases have

579 been ruled out. However, the bias linked with the rockfall locations persists. Indeed, the studied

580 locations were possibly particularly prone to instability (fracturing for example) as much as

581 rockfall dates were favorable for example. For removing this bias, random events should be chosen

582 in all the MBM, with characteristics (altitude, exposure, slope angle...) in accordance with the

583 rockfall sample characteristics. Such a study, in the continuation of this work, could result in the

584 development of a rockfall susceptibility index. This index would be defined with the values of the

585 four variables presented and, particularly, with their significances. This work of gathering all this

586 information could be done by machine learning or deep learning. Some of the real events will be

587 used in the learning process and the others for the testing step. Such a rockfall susceptibility index

588 could be a preliminary step towards a direct societal contribution of the past decade of permafrost

589 research, supporting risk mitigation and public awareness in a rapidly evolving environment.

\section{7. Conclusions}

593 In this paper, the thermal conditions and dynamics at and prior to rockfalls have been analyzed for 594209 events inventoried in the MBM between 2007 and 2015 with 1D temperature modeling. Using 595 temperature measurements at five locations at the rock surface and into three 10-m-deep boreholes, 596 model uncertainty was quantified to refine model interpretation. Based on a random events 597 analysis approach, recent decades of atmospheric warming and seasonal biases have been 598 removed, and the statistical significance of our results was determined. The results were analyzed 599 through surface and scar depth temperature values to discriminate possible processes responsible 600 for rockfall triggering, as well as through temperature percentiles to analyze the statistical 
601 significance and whether the rockfalls are a direct reaction to extreme air temperature signals.

602 Percentiles were defined in relation to 11 temporalities ranging from 1 day to 2 months. KS tests

603 were performed to determine whether our results could have been found from the random sample.

604 Our study draws the following conclusions:

- Permafrost degradation may be responsible for almost all events which scar depth was >

$6066 \mathrm{~m}$, and for a significant part of events occurring between 3 and $6 \mathrm{~m}$ depth.

- For the 209 real events, the surface and scar temperature percentiles were, on average,

608 warmer than those of the random events. This difference is present for all the considered

609 temporalities. It is in order of magnitude of $3 \%$ for scar temperature percentiles (1.5\% at least at

$61095 \%$ reliability level) and $2.5 \%$ for surface temperature percentiles $(0.5 \%$ at least at $95 \%$

611 reliability level).

612

- KS test shows significant relationships between rockfalls and surface temperature

613 percentiles at least up to 2 months prior to failure, and scar temperature percentiles up to 3 weeks

614 before the events. At the rock surface, temporalities $>1$ month have the greatest significance and

615 those of 1-5 days are also remarkable. At scar depths, the closer to the event day, the greater the

616 significance.

617 - Significance results are interpreted as the effects of 1 to 5 days of extraordinary hot 618 weather (hot spell) acting as a triggering mechanism after $>1$ month of exceptionally high air 619 temperature (long lasting heatwave), which result in high temperature at depth and sudden bedrock 620 failure.

621 Decrease of the scar temperature percentiles significances suggests that rockfalls are a 622 direct reaction (lasting less than 3 weeks) to exceptionally high bedrock temperature. 
- When considering $95 \%$ reliability level, uncertainties are too high for concluding

624 anything about KS test significances (the three last points).

- Our study also points out the interest to apply such an approach with a greater rockfall

626 sample to better define the significance levels and appears promising to develop rockfall

627 susceptibility index using weather forecast.

\section{Acknowledgments}

632 This work has been done thanks to the facilities offered by the Univ. Savoie Mont Blanc -

633 CNRS/IN2P3 MUST computing center. We acknowledge S. Westermann from the University of

634 Oslo for providing the CryoGRID model code. This work was supported by the ANR-19-CE01-

6350018 WISPER.

\section{References}

1. Ravanel L, Allignol F, Deline P, Gruber S, Ravello M. Rock falls in the Mont Blanc Massif in 2007 and 2008. Landslides. 2010;7(4):493-501. doi:10.1007/s10346-010-0206-Z

2. Haeberli W, Wegmann M, Vonder Mühll D. Slope stability problems related to glacier shrinkage and permafrost degradation in the Alps. 1997;(90):407-414.

3. Ravanel L, Deline P, Lambiel C, Vincent C. Instability of a High Alpine Rock Ridge: the Lower Arête Des Cosmiques, Mont Blanc Massif, France. Geogr Ann Ser Phys Geogr. 2013;95(1):51-66. doi:10.1111/geoa.12000 infrastructure on permafrost in the French Alps. Reg Environ Change. Published online February 11, 2019. doi:10.1007/s10113-019-01465-z 
5. Bommer $\mathrm{C}$, Institut fédéral de recherches sur la forêt la neige et le paysage (Birmensdorf). Construire sur le pergélisol: guide pratique. Institut fédéral de recherches sur la forêt, la neige et le paysage WSL; 2010.

6. Purdie H, Gomez C, Espiner S. Glacier recession and the changing rockfall hazard: Implications for glacier tourism. N Z Geogr. 2015;71(3):189-202. doi:10.1111/nzg.12091

7. Mourey J, Marcuzzi M, Ravanel L, Pallandre F. Effects of climate change on high Alpine mountain environments: Evolution of mountaineering routes in the Mont Blanc massif (Western Alps) over half a century. Arct Antarct Alp Res. 2019;51(1):176-189. doi:10.1080/15230430.2019.1612216

8. Huggel C, Zgraggen-Oswald S, Haeberli W, et al. The 2002 rock/ice avalanche at Kolka/Karmadon, Russian Caucasus: assessment of extraordinary avalanche formation and mobility, and application of QuickBird satellite imagery. Nat Hazards Earth Syst Sci. 2005;5(2):173-187. doi:https://doi.org/10.5194/nhess-5-173-2005

9. Carey M. Living and dying with glaciers: people's historical vulnerability to avalanches and outburst floods in Peru. Glob Planet Change. 2005;47(2):122-134. doi:10.1016/j.gloplacha.2004.10.007

10. Walter F, Amann F, Kos A, et al. Direct observations of a three million cubic meter rockslope collapse with almost immediate initiation of ensuing debris flows. Geomorphology. 2020;351:106933. doi:10.1016/j.geomorph.2019.106933

11. Allen SK, Rastner P, Arora M, Huggel C, Stoffel M. Lake outburst and debris flow disaster at Kedarnath, June 2013: hydrometeorological triggering and topographic predisposition. Landslides. 2016;13(6):1479-1491. doi:10.1007/s10346-015-0584-3

12. Haeberli W, Huggel C, Kääb A, et al. The Kolka-Karmadon rock/ice slide of 20 September 2002: an extraordinary event of historical dimensions in North Ossetia, Russian Caucasus. $J$ Glaciol. 2004;50(171):533-546. doi:10.3189/172756504781829710

13. Huggel C, Allen S, Deline P, Fischer L, Noetzli J, Ravanel L. Ice thawing, mountains falling — are alpine rock slope failures increasing? Geol Today. 2012;28(3):98-104. doi:10.1111/j.1365-2451.2012.00836.x

14. Fischer L, Purves RS, Huggel C, Noetzli J, Haeberli W. On the influence of topographic, geological and cryospheric factors on rock avalanches and rockfalls in high-mountain areas. Nat Hazards Earth Syst Sci. 2012;12(1):241-254. doi:https://doi.org/10.5194/nhess-12-2412012

15. Ravanel L, Deline P. Climate influence on rockfalls in high-Alpine steep rockwalls: The north side of the Aiguilles de Chamonix (Mont Blanc massif) since the end of the 'Little Ice Age.' The Holocene. 2011;21(2):357-365. doi:10.1177/0959683610374887 
683

684

685

686

687

688

689

690

691

692

693

694

695

696

697

698

699

700

701

702

703

704

705

706

707

708

709

710

711

712

713

714

715

716

717

718

16. Deline P, Gardent M, Magnin F, Ravanel L. The Morphodynamics of the Mont Blanc Massif in a Changing Cryosphere: A Comprehensive Review. Geogr Ann Ser Phys Geogr. 2012;94(2):265-283. doi:10.1111/j.1468-0459.2012.00467.x

17. Allen SK, Gruber S, Owens IF. Exploring steep bedrock permafrost and its relationship with recent slope failures in the Southern Alps of New Zealand. Permafr Periglac Process. 2009;20(4):345-356. doi:10.1002/ppp.658

18. Allen SK, Cox SC, Owens IF. Rock avalanches and other landslides in the central Southern Alps of New Zealand: a regional study considering possible climate change impacts. Landslides. 2011;8(1):33-48. doi:10.1007/s10346-010-0222-z

19. Gruber S, Hoelzle M, Haeberli W. Permafrost thaw and destabilization of Alpine rock walls in the hot summer of 2003. Geophys Res Lett. 2004;31(13). doi:10.1029/2004GL020051

20. Ravanel L, Magnin F, Deline P. Impacts of the 2003 and 2015 summer heatwaves on permafrost-affected rock-walls in the Mont Blanc massif. Sci Total Environ. 2017;609:132143. doi:10.1016/j.scitotenv.2017.07.055

21. Deline P, Broccolato M, Noetzli J, Ravanel L, Tamburini A. The December 2008 Crammont Rock Avalanche, Mont Blanc Massif Area, Italy. In: Margottini C, Canuti P, Sassa K, eds. Landslide Science and Practice: Volume 4: Global Environmental Change. Springer; 2013:403-408. doi:10.1007/978-3-642-31337-0_52

22. Frauenfelder R, Isaksen K, Lato MJ, Noetzli J. Ground thermal and geomechanical conditions in a permafrost-affected high-latitude rock avalanche site (Polvartinden, northern Norway). The Cryosphere. 2018;12(4):1531-1550. doi:https://doi.org/10.5194/tc-12-15312018

23. Deline P, Gruber S, Delaloye R, et al. Chapter 15 - Ice Loss and Slope Stability in HighMountain Regions. In: Shroder JF, Haeberli W, Whiteman C, eds. Snow and Ice-Related Hazards, Risks and Disasters. Academic Press; 2015:521-561. doi:10.1016/B978-0-12394849-6.00015-9

24. Krautblatter M, Funk D, Günzel FK. Why permafrost rocks become unstable: a rock-icemechanical model in time and space. Earth Surf Process Landf. 2013;38(8):876-887. doi:10.1002/esp.3374

25. Gruber S, Haeberli W. Permafrost in steep bedrock slopes and its temperature-related destabilization following climate change. J Geophys Res Earth Surf. 2007;112(F2). doi:10.1029/2006JF000547

26. Magnin F, Josnin J-Y, Ravanel L, Pergaud J, Pohl B, Deline P. Modelling rock wall permafrost degradation in the Mont Blanc massif from the LIA to the end of the 21st century. The Cryosphere. 2017;11(4):1813-1834. doi:https://doi.org/10.5194/tc-11-18132017 
27. Davies MCR, Hamza O, Harris C. The effect of rise in mean annual temperature on the stability of rock slopes containing ice-filled discontinuities. Permafr Periglac Process. 2001;12(1):137-144. doi:10.1002/ppp.378

28. Mamot P, Weber S, Schröder T, Krautblatter M. A temperature- and stress-controlled failure criterion for ice-filled permafrost rock joints. The Cryosphere. 2018;12(10):3333-3353. doi:10.5194/tc-12-3333-2018

29. Matsuoka N, Sakai H. Rockfall activity from an alpine cliff during thawing periods. Geomorphology. 1999;28(3):309-328. doi:10.1016/S0169-555X(98)00116-0

30. Hasler A, Gruber S, Font M, Dubois A. Advective Heat Transport in Frozen Rock Clefts: Conceptual Model, Laboratory Experiments and Numerical Simulation. Permafr Periglac Process. 2011;22(4):378-389. doi:10.1002/ppp.737

31. Krautblatter M, Hauck C. Electrical resistivity tomography monitoring of permafrost in solid rock walls. J Geophys Res Earth Surf. 2007;112(F2). doi:10.1029/2006JF000546

32. Phillips M, Haberkorn A, Draebing D, Krautblatter M, Rhyner H, Kenner R. Seasonally intermittent water flow through deep fractures in an Alpine Rock Ridge: Gemsstock, Central

33. Krautblatter M, Huggel C, Deline P, Hasler A. Research Perspectives on Unstable Highalpine Bedrock Permafrost: Measurement, Modelling and Process Understanding. Permafr Periglac Process. 2012;23(1):80-88. doi:10.1002/ppp.740

34. Fischer L, Amann F, Moore JR, Huggel C. Assessment of periglacial slope stability for the 1988 Tschierva rock avalanche (Piz Morteratsch, Switzerland). Eng Geol. 2010;116(1):3243. doi:10.1016/j.enggeo.2010.07.005

35. Magnin F, Brenning A, Bodin X, Deline P, Ravanel L. Statistical modelling of rock wall permafrost distribution: application to the Mont Blanc massif. Géomorphologie Relief Process Environ. Published online 2015:20.

36. Paranunzio R, Laio F, Chiarle M, Nigrelli G, Guzzetti F. Climate anomalies associated with the occurrence of rockfalls athigh-elevation in the Italian Alps. Nat Hazards Earth Syst Sci. 2016;16(9):2085-2106. doi:10.5194/nhess-16-2085-2016

37. Luethi R, Gruber S, Ravanel L. Modelling transient ground surface temperatures of past rockfall events: towards a better understanding of failure mechanisms in changing periglacial environments. Geogr Ann Ser Phys Geogr. 2015;97(4):753-767. doi:10.1111/geoa.12114

38. Allen S, Huggel C. Extremely warm temperatures as a potential cause of recent high mountain rockfall. Glob Planet Change. 2013;107:59-69. doi:10.1016/j.gloplacha.2013.04.007 
754

755

756

757

758

759

760

761

762

763

764

765

766

767

768

769

770

771

772

773

774

775

776

777

778

779

780

781

782

783

784

785

786

787

788

789

39. Bakun-Mazor D, Keissar Y, Feldheim A, Detournay C, Hatzor YH. Thermally-Induced Wedging-Ratcheting Failure Mechanism in Rock Slopes. Rock Mech Rock Eng. 2020;53(6):2521-2538. doi:10.1007/s00603-020-02075-6

40. Collins BD, Stock GM. Rockfall triggering by cyclic thermal stressing of exfoliation fractures. Nat Geosci. 2016;9(5):395-400. doi:10.1038/ngeo2686

41. Hugentobler M, Loew S, Aaron J, Roques C, Oestreicher N. Borehole monitoring of thermohydro-mechanical rock slope processes adjacent to an actively retreating glacier. Geomorphology. 2020;362:107190. doi:10.1016/j.geomorph.2020.107190

42. Westermann S, Schuler TV, Gisnås K, Etzelmüller B. Transient thermal modeling of permafrost conditions in Southern Norway. The Cryosphere. 2013;7(2):719-739. doi:10.5194/tc-7-719-2013

43. Schär C, Vidale PL, Lüthi D, et al. The role of increasing temperature variability in European summer heatwaves. Nature. 2004;427(6972):332-336. doi:10.1038/nature02300

44. Gobiet A, Kotlarski S, Beniston M, Heinrich G, Rajczak J, Stoffel M. 21st century climate change in the European Alps-A review. Sci Total Environ. 2014;493:1138-1151. doi:10.1016/j.scitotenv.2013.07.050

45. Christidis N, Jones GS, Stott PA. Dramatically increasing chance of extremely hot summers since the 2003 European heatwave. Nat Clim Change. 2015;5(1):46-50. doi:10.1038/nclimate2468

46. Haeberli W, Noetzli J, Arenson L, et al. Mountain permafrost: development and challenges of a young research field. J Glaciol. 2010;56(200):1043-1058. doi:10.3189/002214311796406121

47. von Raumer JF, Bussy F. Mont Blanc and Aiguilles Rouges Geology of Their Polymetamorphic Basement (External Massifs, Western Alps, France-Switzerland). Section des Sciences de la Terre, Université de Lausanne; 2004:218. https://www.unil.ch/iste/files/live/sites/iste/files/shared/X.Library/Memoirs\%20of\%20Geolo gy/42\%20-\%20Von\%20Raumer\%20\%26\%20Bussy\%20(2004\%20-

$\% 20$ entire\%20volume).pdf

48. Gardent M, Rabatel A, Dedieu J-P, Deline P. Multitemporal glacier inventory of the French Alps from the late 1960s to the late 2000s. Glob Planet Change. 2014;120:24-37. doi:10.1016/j.gloplacha.2014.05.004

49. Magnin F, Deline P, Ravanel L, Noetzli J, Pogliotti P. Thermal characteristics of permafrost in the steep alpine rock walls of the Aiguille du Midi (Mont Blanc Massif, $3842 \mathrm{~m}$ a.s.1). The Cryosphere. 2015;9(1):109-121. doi:10.5194/tc-9-109-2015

50. Ravanel L, Deline P. A network of observers in the Mont Blanc massif to study rockfalls in high alpine rockwalls. Geogr Fis E Din Quat. 2013;(36):151-158. 
51. Boeckli L, Brenning A, Gruber S, Noetzli J. A statistical approach to modelling permafrost distribution in the European Alps or similar mountain ranges. The Cryosphere. 2012;6(1):125-140. doi:10.5194/tc-6-125-2012

52. Hasler A, Gruber S, Haeberli W. Temperature variability and offset in steep alpine rock and ice faces. The Cryosphere. 2011;5(4):977-988. doi:https://doi.org/10.5194/tc-5-977-2011

53. Noetzli J, Gruber S, Kohl T, Salzmann N, Haeberli W. Three-dimensional distribution and evolution of permafrost temperatures in idealized high-mountain topography. J Geophys Res Earth Surf. 2007;112(F2). doi:10.1029/2006JF000545

54. Rolland C. Spatial and Seasonal Variations of Air Temperature Lapse Rates in Alpine Regions. J Clim. 2003;16(7):1032-1046. doi:10.1175/15200442(2003)016<1032:SASVOA>2.0.CO;2

55. Noetzli J, Gruber S, Kohl T, Salzmann N, Haeberli W. Three-dimensional distribution and evolution of permafrost temperatures in idealized high-mountain topography. J Geophys Res. 2007;112(F2):F02S13. doi:10.1029/2006JF000545

56. Luethi R, Gruber S, Ravanel L. Modelling transient ground surface temperatures of past rockfall events: towards a better understanding of failure mechanisms in changing periglacial environments. Geogr Ann Ser Phys Geogr. 2015;97(4):753-767. doi:10.1111/geoa.12114

57. Magnin F, Westermann S, Pogliotti P, Ravanel L, Deline P, Malet E. Snow control on active layer thickness in steep alpine rock walls (Aiguille du Midi, 3842ma.s.l., Mont Blanc massif). CATENA. 2017;149:648-662. doi:10.1016/j.catena.2016.06.006

58. Loucks DP, Beek E van, Stedinger JR. Water Resources Systems Planning and Management: An Introduction to Methods, Models and Applications. UNESCO; 2005.

59. Magnin F, Brenning A, Bodin X, Deline P, Ravanel L. Modélisation statistique de la distribution du permafrost de paroi : application au massif du Mont Blanc. Géomorphologie Relief Process Environ. 2015;21(vol. 21 - n 2):145-162. doi:10.4000/geomorphologie.10965

60. Magnin F, Deline P, Ravanel L, Noetzli J, Pogliotti P. Thermal characteristics of permafrost in the steep alpine rock walls of the Aiguille du Midi (Mont Blanc Massif, $3842 \mathrm{~m}$ a.s.l). The Cryosphere. 2015;9(1):109-121. doi:https://doi.org/10.5194/tc-9-109-2015

61. Hall $\mathrm{K}$. The role of thermal stress fatigue in the breakdown of rock in cold regions. Geomorphology. 1999;31(1-4):47-63. doi:10.1016/S0169-555X(99)00072-0

62. Sass O. Rock Moisture Fluctuations During Freeze-thaw Cycles: Preliminary Results from Electrical Resistivity Measurements. Polar Geogr. 2004;28(1):13-31. doi:10.1080/789610157

63. Matsuoka N. Direct observation of frost wedging in alpine bedrock. Earth Surf Process Landf. 2001;26(6):601-614. doi:10.1002/esp.208 
826

827

828

829

830

831

832

833

834

835

836

837

838

839

840

841

842

843

844

845

846

64. McColl ST, Draebing D. Rock Slope Instability in the Proglacial Zone: State of the Art. In: Heckmann T, Morche D, eds. Geomorphology of Proglacial Systems: Landform and Sediment Dynamics in Recently Deglaciated Alpine Landscapes. Geography of the Physical Environment. Springer International Publishing; 2019:119-141. doi:10.1007/978-3-31994184-4_8

65. Matsuoka N, Murton J. Frost weathering: recent advances and future directions. Permafr Periglac Process. 2008;19(2):195-210. doi:10.1002/ppp.620

66. Draebing D, Krautblatter M. The Efficacy of Frost Weathering Processes in Alpine Rockwalls. Geophys Res Lett. 2019;46(12):6516-6524. doi:10.1029/2019GL081981

67. Jia H, Xiang W, Krautblatter M. Quantifying Rock Fatigue and Decreasing Compressive and Tensile Strength after Repeated Freeze-Thaw Cycles. Permafr Periglac Process. 2015;26(4):368-377. doi:10.1002/ppp.1857

68. Vargas EAJr, Veloso RQ, Chavez LE, Gusmão L, Amaral CP. On the Effect of Thermally Induced Stresses in Failures of Some Rock Slopes in Rio de Janeiro, Brazil. springerprofessional.de. 2012;46:123-134.

69. Gunzburger Y, Merrien-Soukatchoff V, Guglielmi Y. Influence of daily surface temperature fluctuations on rock slope stability: case study of the Rochers de Valabres slope (France). Int J Rock Mech Min Sci. 2005;3(42):331-349. doi:10.1016/j.ijrmms.2004.11.003

70. Robinson PJ. On the Definition of a Heat Wave. J Appl Meteorol. 2001;40(4):762-775. doi:10.1175/1520-0450(2001)040<0762:OTDOAH>2.0.CO;2 
847 Table 1. Summary characteristics of the 209 rockfall events used in this study. MARST refers to the

848 Mean Annual Rock Surface Temperature such as displayed in Figure 1.

\begin{tabular}{l|l|l|l|l|l}
\hline & Altitude $(\mathbf{m})$ & MARST $\left({ }^{\circ} \mathbf{C}\right)$ & Volume $\left(\mathbf{m}^{3}\right)$ & $\begin{array}{l}\text { Scar depth } \\
(\mathbf{m})\end{array}$ & Slope angle $\left(^{\circ}\right)$ \\
& & & & & \\
\hline Minimum & 2175 & -8.7 & 100 & 0.8 & $12^{*}$ \\
Mean & 3341 & -2 & 1836 & 3 & 57 \\
Median & 3355 & -2 & 400 & 3.8 & 57 \\
Maximum & 4085 & 4 & 60000 & 15 & 82 \\
\hline
\end{tabular}

849

850 Table 1: Optimum parameters for minimizing the RMSE between simulated and real borehole temperatures. * This

851 low value is explained by the fact that the rockfall occurred from the top of a crest.

\begin{tabular}{l|l}
\hline \multicolumn{1}{c|}{ Parameter } & \multicolumn{1}{c}{ Value } \\
\hline Bedrock conductivity $\left(\mathrm{k}_{\text {bedrock }}\right)$ & $3.3 \mathrm{~W} \cdot \mathrm{m}^{-1} \cdot \mathrm{K}^{-1}$ \\
\hline Bedrock porosity $(\varphi)$ & $1 \%$ \\
\hline Total water content $\left(\theta_{\mathrm{w}, \mathrm{tot}}\right)$ & $1 \%$ \\
\hline Bedrock volumetric heat capacity & $2.10^{6} \mathrm{~J} \cdot \mathrm{m}^{-3} \cdot \mathrm{K}^{-1}$ \\
\hline Profile resolution & From 1 to $3 \mathrm{~m}: 0.1 \mathrm{~m}$ \\
& From 3 to $10 \mathrm{~m}: 0.2 \mathrm{~m}$ \\
\hline Spin-up duration & From $10 \mathrm{~m}$ to $20.5 \mathrm{~m}: 0.5 \mathrm{~m}$ \\
\hline $\mathrm{C}_{\text {exp }}$ & 3 years \\
\hline
\end{tabular}

